Finlands svenska folkmusikinstituts småskrifter 1

\title{
Från knutdans till \\ spelmansstämma
}

Spelmansmusiken under 100 år.

ANN-MARI HÄGGMAN

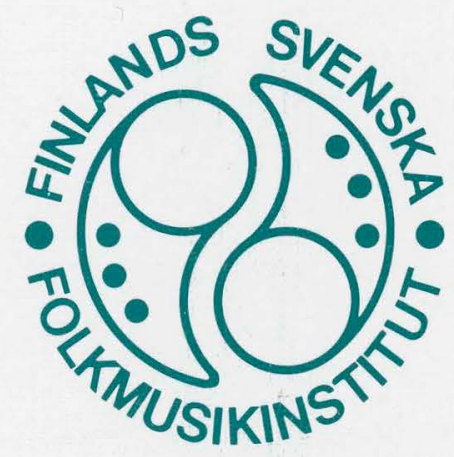

Artikel ur:

MUSIK • SÅNG • FEST 1891 - 1991

De finlandssvenska sångfesterna som

kulturföreteelse och impulsgivare

Finlands svenska sång och musikförbund 1991 



\section{Från knutdans till spelmansstämma}

Spelmansmusiken under 100 år. 
Finlands svenska folkmusikinstituts småskrifter 1

Ombrytning: Synnöve Svanström

Dipro offset, Vasa 1991.

ISBN 952-9669-00-3 


\title{
Från knutdans till spelmansstämma
}

Spelmansmusiken under 100 år.

\author{
ANN-MARI HÄGGMAN
}

Artikel ur:

MUSIK • SÅNG • FEST 1891 - 1991

De finlandssvenska sångfesterna som kulturföreteelse och impulsgivare

Finlands svenska sång och musikförbund 1991

Finlands svenska folkmusikinstitut

Vasa 


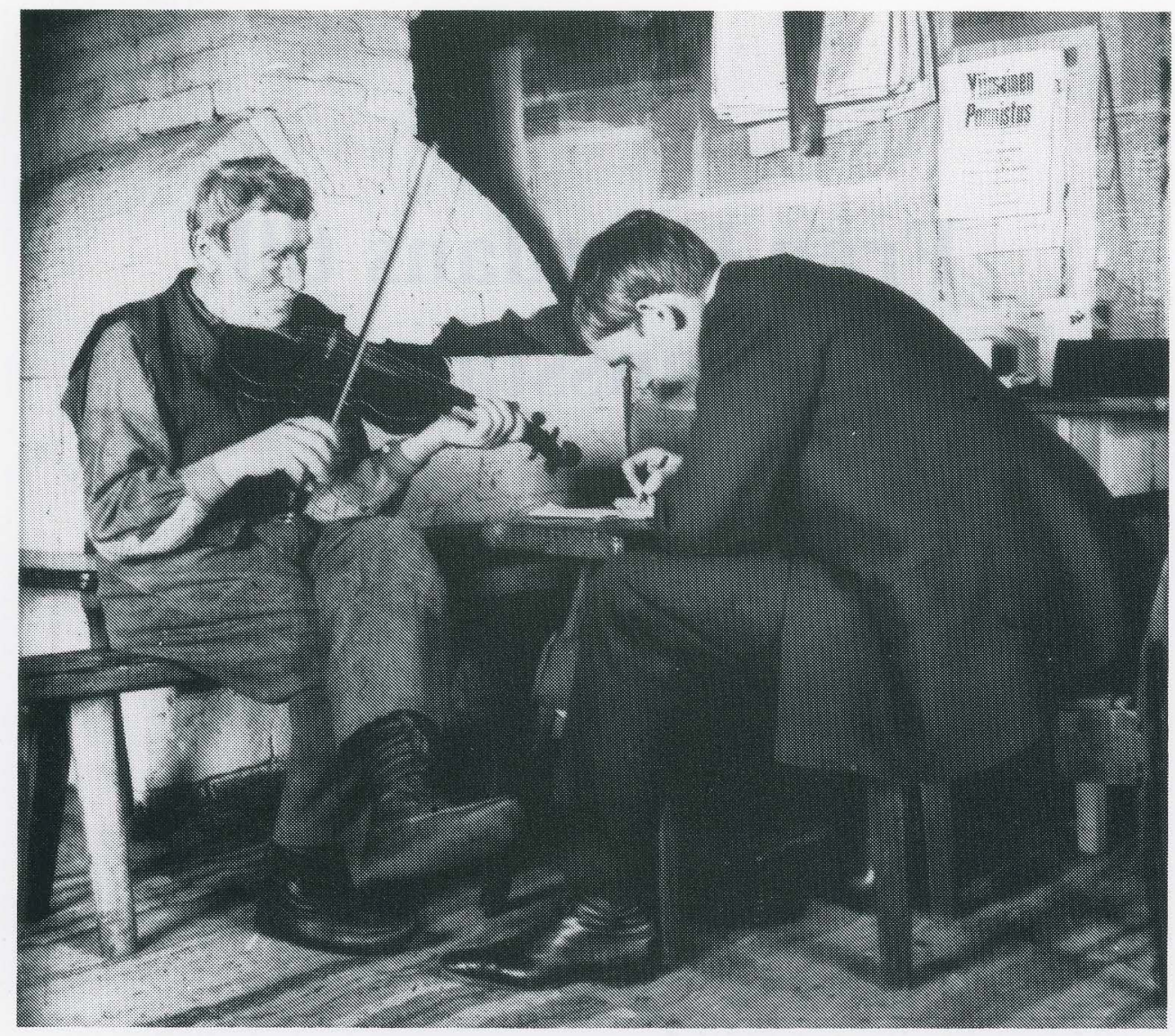

Otto Andersson tecknar upp melodier efter Erik Lönnberg $i$ Vittisbofjärd 1912.

Foto: Gösta Widbom. (SLS, Folkkultursarkivet, Helsingfors)

Folkmusiken har sina rötter i ett samhälle som var mycket olikt dagens urbana samhälle. I 1800-talets landsbygdssamhälle var spelmannen hedersgäst vid bröllop och knutdanser. Samhället behövde musik, han var den som levererade musiken. I början av 1900-talet organiserades ungdomslivet och musiklivet på ett nytt sätt. Föreningsfester av olika slag ersatte ungdomarnas improviserade danstillställningar. I samband med sångfester anordnades spelmanstävlingar, som skapade nya ideal. På 1940-talet tillkom de första spelmanslagen och 1969 slöt sig spelmännen samman till ett eget förbund, Finlands svenska spelmansförbund. Om bondesamhällets musikanter som blev "allmogespelmän" handlar denna uppsats. 


\title{
Från knutdans till spelmansstämma
}

\author{
Spelmansmusiken under 100 år.
}

ANN-MARI HÄGGMAN

Dagens spelmansmusik har sina rötter i ett samhälle, som var mycket olikt det samhälle vi upplever i dag. Vi behöver bara gå ett sekel tillbaka i tiden för att finna byarna som fasta små enheter, självförsörjande också vad spelmän och musik beträffar. När ungdomarna om söndagskvällarna samlades till sina improviserade knutdanser i bondstugorna, var spelmannen hedersgästen. Han var den som först blev tillfrågad och han undfägnades på bästa sätt. Det var han som bestämde vad som skulle dansas och ofta var det han som lärde ut nya danser. Vid bröllopen var han ceremonimästaren, som gick före brudparet i bröllopsföljet och som satt bland hedersgästerna vid brudparets bord. Spelmannen fyllde en viktig social funktion; samhället behövde musik och han levererade musiken.

Man brukar räkna med att bondesamhället gick mot sin upplösning vid tiden kring sekelskiftet, då industrialiseringen ledde till en flyttningsrörelse, storskiftet sprängde byarna, kommunikationerna förbättrades, läskunnigheten blev allmän och den muntliga traditionen försvagades. Då förändrades ungdomarnas nöjesvanor och därmed försvagades också spelmännens ställning. Ungdomsföreningarna organiserade nöjeslivet på ett nytt sätt. Lärare och studerat folk

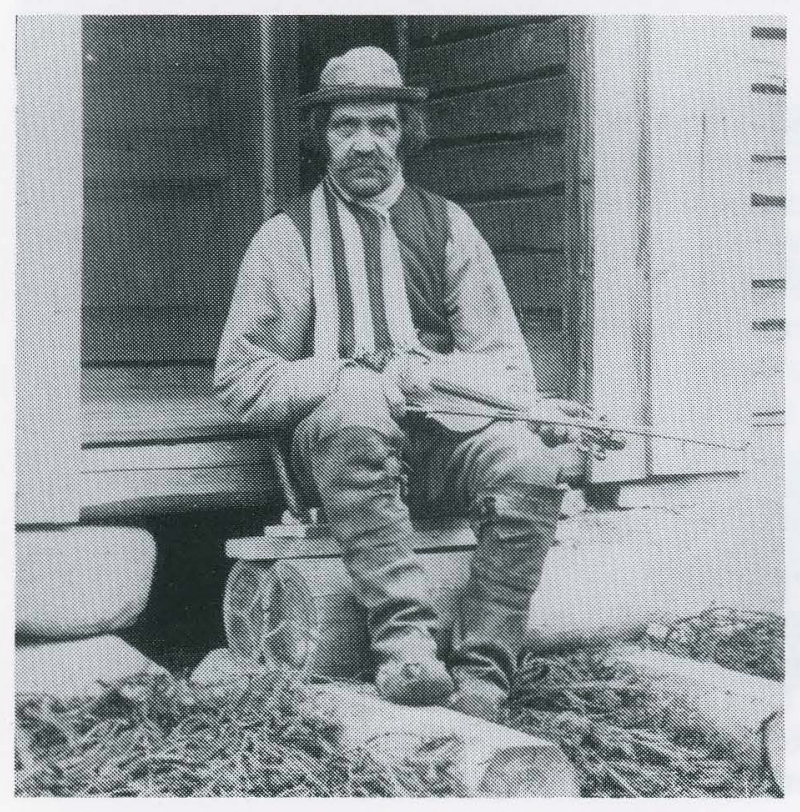

Spelmannen och torparen Johan Johansson Bränn (1838-1918), Purmo.

Foto: Otto Andersson 1904. (SLS, Folkkultursarkivet, Helsingfors) 


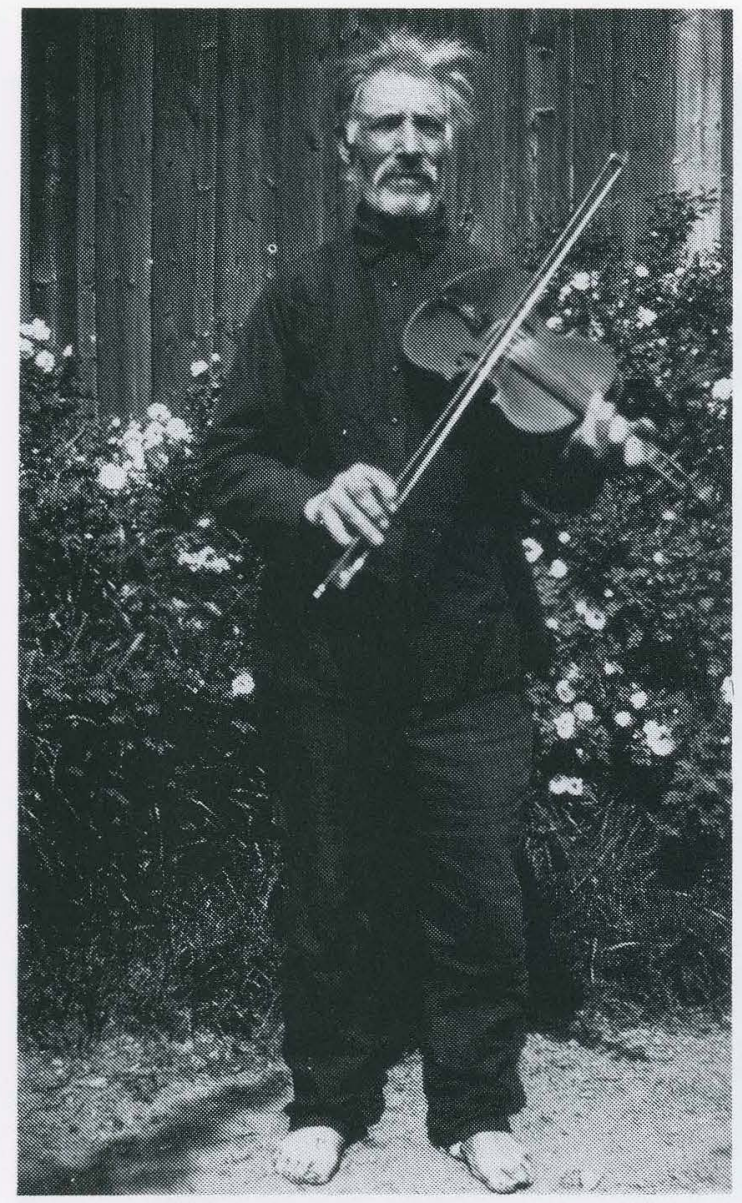

Johan Erik Taklax (f. 1856), Korsnäs.

Foto: Alfhild Forslin 1930. (SLS, Folkkultursarkivet, Helsingfors)

ställde sig i ledningen. De strävade till att höja folkbildningen genom att inrätta läsesalar och genom att anordna månadsmöten, diskussionsaftnar och kulturella program vid olika fester. I stället för knutdanser blev det nu höstfester, skördefester, julfester, nyårsfester, skyddskårsfester, lotterier och soaréer med dans. Ungdomens fritidsverksamhet koncentrerades alltmer till de föreningshus, som under seklets två första decennier växte upp på vår landsbygd. Där föreningshus byggdes, där försvann ungdomarnas improviserade danstillställningar. Sammankomsterna organiserades nu på ett annat sätt. Ofta låg en tanke på ekonomisk vinning bakom arrangemangen. Publiken betalade inträdesavgift, medan föreningen stod för lokal och avlönade musiken. I föreningshusens stora danslokaler kunde en eller två fioler inte längre göra sig hörda. En del spelmän anpassade sig till tidens krav och slöt sig samman till dansorkestrar, andra gav upp i den hårdnande konkurrensen.

Men samhället förändras långsamt. Ända fram till andra världskriget var bygemenskapen stark och i en del byar levde spelmansmusiken kvar på nästan traditionellt sätt. Ännu i dag finner vi samhällen, där musiken lever i muntlig tradition, där spelmännen lär sig låtar genom att höra andra spelmän spela dem och där en lokal spelstil dominerar. En sådan traditionell spelmansmusik finner vi t.ex. i Jeppo, där Jeppo bygdespelmän 1985 erhöll Europapriset i folkkonst som erkänsla för en unik traditionsmedvetenhet och konstnärligt musikframförande. ${ }^{1}$ 


\section{Rädda fiollåtarna}

Det var under 1800-talets senare del som de lärda hos oss började uppmärksamma den musik, som levde ute i bygderna. Lärare och studenter vandrade runt och tecknade upp menuetter och polskor efter byspelmännens framförande. De kunde då inte undgå att notera att det traditionella fiolspelandet på landsbygden var på tillbakagång. Förhållandena var desamma överallt i Norden och kulturmedvetna personer på olika håll började uttrycka farhågor för att den musik, som till dess levt rätt oföränderlig i ett statiskt bondesamhälle, helt plötsligt skulle försvinna och ersättas av något nytt; det gällde att ta tillvara så mycket som möjligt av den gehörsbundna traditionen innan den helt och hållet försvann.

När eleven vid Helsingfors musikinstitut, Otto Andersson, 1902 som Svenska litteratursällskapets stipendiat tecknade upp spelmanslåtar i Närpes kunde han besviket konstatera, att det inte var så lätt att få tag på spelmän, som fortfarande hanterade fiolen: "Där någon fiol ännu als fans kvar, låg denna merändels på någon hylla, utan strängar och höljd af dam, och från 'danslafvarna' hördes om kvällarna blott harmonikornas andfädda framstönande af någon polka eller annan 'nymodig' dans. ${ }^{12}$ Och Otto Andersson såg som sin uppgift att rädda de gamla låtarna till eftervärlden. När han vid litteratursällskapets möte den 22 oktober 1903 redogjorde för sin insamling, avslutade han sitt föredrag med att påpeka hur försummad denna forskningssektor var och med att uppmana till fortsatt insamling: "Vår plikt är därför att se till, att så mycket som möjligt af dessa skatter räddas undan förgängelsen. Det är redan i elfte stunden, ty efter högst ett tiotal år skall man knappt finna något spår mer af violinspel på landsbygden, och på samma gång äro också melodierna för alltid försvunna. Vi ha icke råd att mista så mycket. Vi måste taga oss an dessa hemlösa skogarnas och ödemarkernas barn, hvilka hafva så mycket att berätta oss frän sitt okända hem och sina irrande färder."3

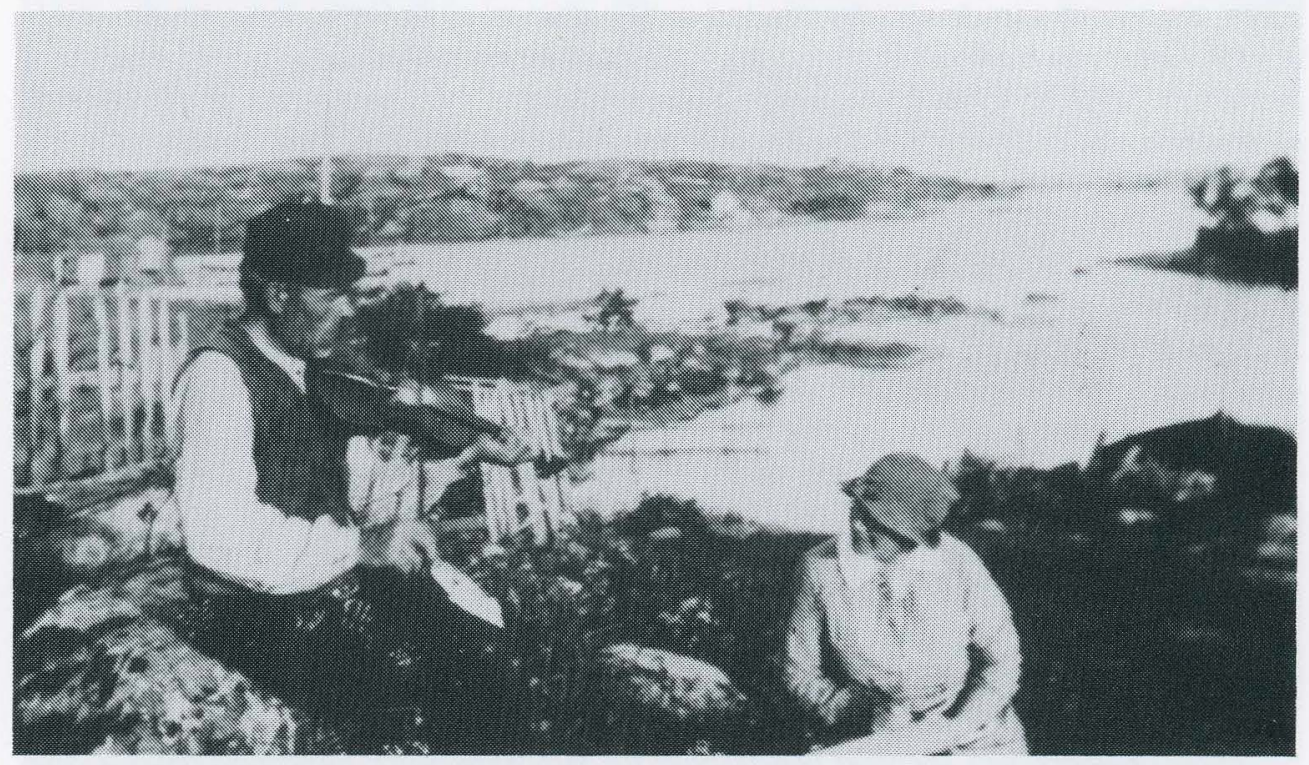

Greta Stenbäck (Dahlström) tecknar upp låtar efter Konrad Blomqvist, Houtskär, Äpplö, sommaren 1923. (SLS, Folkkultursarkivet, Helsingfors) 
Vid den här tiden tog spelmansrörelsen i Sverige fart. Konstnären Anders Zorn ville återuppliva den gamla utdöende konsten att blåsa horn samtidigt som han ville rädda de gamla fiollåtarna. Därför anordnade han år 1906 i Gesunda i Mora en tävling för hornblåserskor och fiolspelmän. Detta var upptakten och tävlingsidén spred sig sedan med hast över hela Sverige och nådde också Finland. Bäst kom den till synes inom Föreningen Brage, där Otto Andersson var den drivande kraften. ${ }^{4}$

Föreningen Brage i Helsingfors grundades 1906. Dess uppgift blev att vårda och återuppliva finlandssvensk folkkultur i sång och musik, dräkter och danser. Redan vid ett allmänt föreningsmöte våren 1906 diskuterade man på vilket sätt föreningen verksammast skulle kunna bidraga till att återuppliva fiolspelet på landsbygden. "Frågan, som inleddes av herr Andersson, föranledde en ganska livlig och intressant diskussion, varvid som orsak till den nedåtgående spelskickligheten framhölls i främsta rummet dragspelets inträngande, vilket underlättas därigenom, att harmonikan är så mycket lättspeltare; men även hornmusiken ansågs av allmogen såsom förnämare än den gamla goda fiollåten". Mötet ansåg att man kunde försöka stöda fiolspelet genom att underlätta tillgången till instrument och genom att anordna tävlingar för fiolspelmän i samband med hembygdsfester och sångfester, såsom man redan gjort på en del håll i Österbotten. ${ }^{5}$

\section{Spelmanstävlingarna}

När sång- och musikfesten 1907 anordnades i Helsingfors förlade Brage sin vårfest till samma tid och inbjöd fiolspelmännen till en spelmanstävlan. Femtiosex spelmän hörsammade kallelsen. Det var första gången spelmännen samlades i huvudstaden och tidningarna ägnade händelsen stor uppmärksamhet. Hufvudstadsbladets signatur "Bis" skrev: "Det var en ärevördig syn att se dessa $i$ sin konst delvis redan gränade spelmän. Deras ansiktsuttryck angaf ett varmt, inspireradt uppgående i det föredragna, angaf att dessa violinmusikens representanter ochförsvarare mot harmonikans vulgära intrång fattat sin sak med allvar och en viss berättigad grandezza." ${ }^{16}$ Cch Nya Pressens signatur "K" konstaterade: "På någon 'konst' i högre mening bjödo dessa enkla allmogemusikanter naturligtvis icke. Men det var af stort intresse att lyssna till deras landtliga låtar, valser, polkor och potpourrier, några nog så genuina och föreskrifvande sig frän fädrens tid, andra moderna uppkok, så att hvarken 'Fischerin du kleine' eller Kväsarvalsen saknades. --- Nog så lustiga musikanttyper såg man."

Benämningar som "allmogespelman" och "folkmusik" började nu dyka upp. Det var benämningar som användes av dem, som stod utanför traditionen. Begreppen markerar ju ett visst avstånd. Kultureliten behövde begrepp för att skilja dessa musikanter och deras musik från den musikutövning de själva uppfattade som den gängse musiken. En spelman själv skulle vid tiden kring sekelskiftet aldrig kallat sin musik för folkmusik, lika litet som han kallade sig allmogespelman. Han var spelman rätt och slätt, och det han spelade var musik - den musik som hans samhälle kände till och behövde.

Efter Brages första lyckade spelmanstävling hölls spelmanstävlingar regelbundet i Helsingfors och på landsorten - flitigast tävlade man i Mariehamn, Vasa och Kristinestad. Ett trettiotal spelmän möttes vanligen i ädel tävlan. Tävlingarna hade i stort sett samma förlopp. En efter en framförde spelmännen sina låtar från scen och utförandet poängsattes av några domare. Slutligen samlades alla spelmän och utförde till publikens stora förtjusning ett par låtar tillsammans. 1911 kunde Hufvudstadsbladet konstatera, att "herr Otto Anderssons ifriga bemödanden att höja violinspelet på landsbygden hade burit goda frukter." 


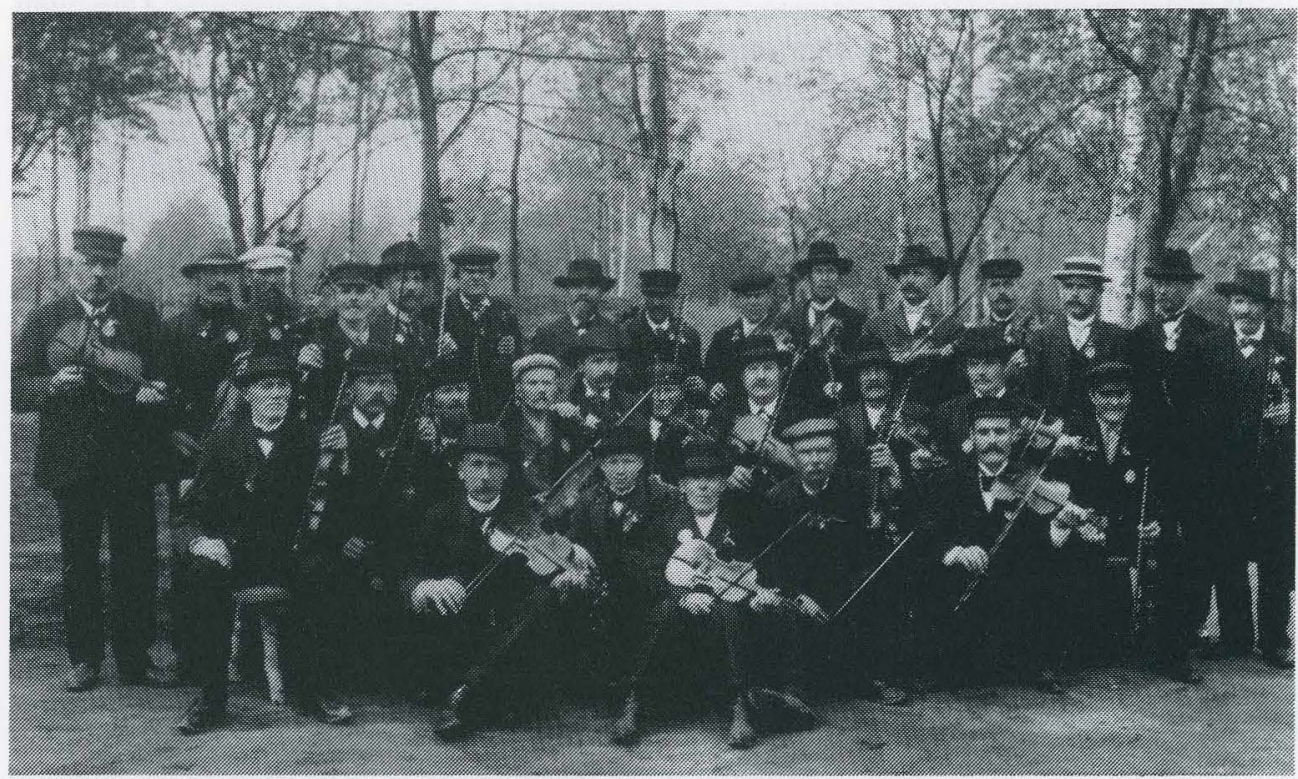

I samband med saing- och musikfesten i Helsingfors 1907 höll Föreningen Brage sin första spelmanstävling. Initiativtagare var Otto Andersson ( $i$ mitten $i$ andra raden). (SLS, Folkkultursarkivet, Helsingfors)

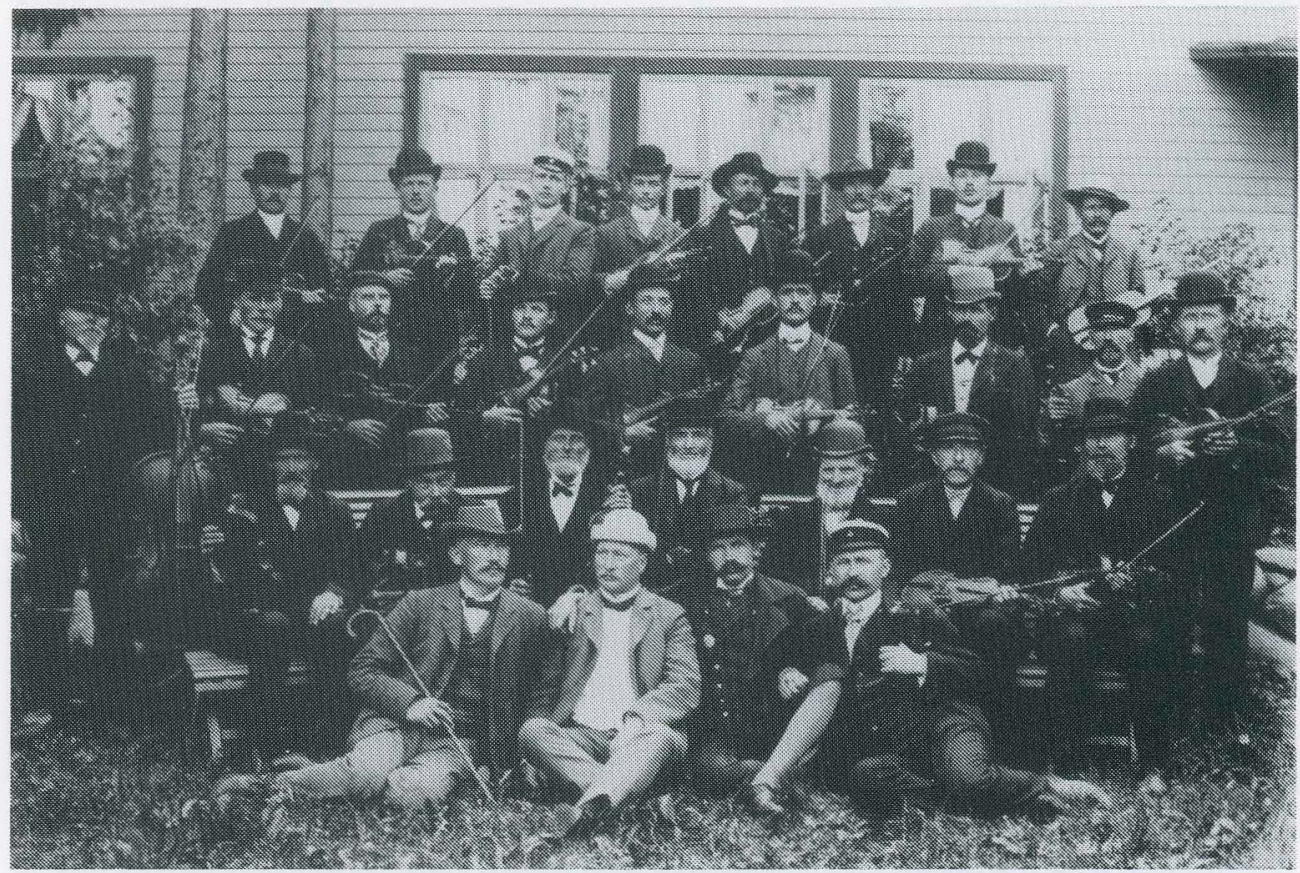

Deltagarna vid spelmanstävlingen i Mariehamn 1908.

(SLS, Folkkultursarkivet, Helsingfors) 
Betydelsen av dessa första spelmanssammankomster kan knappast överskattas. Uppmuntrade av det nya intresset från allmänhetens och kulturelitens sida tog spelmännen sina gamla instrument till heders igen, höll dem i skick, förbättrade dem och började öva de gamla melodierna. Prisdomarna gav poäng inte bara för ett skickligt utförande och god spelstil; en låt av hög ålder gav mer poäng än en yngre. Tävlingarna skapade vissa mönster och ideal, som kom att bli gällande för spelmansmusikens fortsatta praktiska användning.

Första världskriget vållade ett visst avbräck men efter någon tid tog spelmanstävlingarna ny fart. Tävlingarna var stora publiksuccéer. De blev populära inslag vid lokala sång- och musikfester, vid hembygdsfester och brandkårsfester. När Föreningen Brage i Vasa i samband med sitt midsommarfirande 1921 anordnade en spelmanstävlan i stadshusets festsal slogs man formligen om platserna "och då både salongen och läktaren voro fyllda till trängsel, fanns det ännu lika många, som fingo vända om i trapporna. ${ }^{\text {"9 }}$

Till en början ställde spelmännen rätt villigt upp på dessa tävlingar. Möjlighet till pris, ära och berömmelse var en stor lockelse för spelmän, som visste att de behärskade fiolen. Tävlingarna var efterlängtade avbrott i en annars ganska enahanda tillvaro. För dem som levde i små omständigheter gav tävlingarna möjlighet till en liten extra inkomst. Pengar stod betydligt högre i kurs än medaljer och pokaler. När Övermark-spelmannen Johan Petter Ragvals en gång i Närpes vann en silverpokal, tog han litet föraktfullt emot den. "Kva ska ja me hede?", lär han ha sagt. Han ville ha pengar inte en pokal. ${ }^{10}$

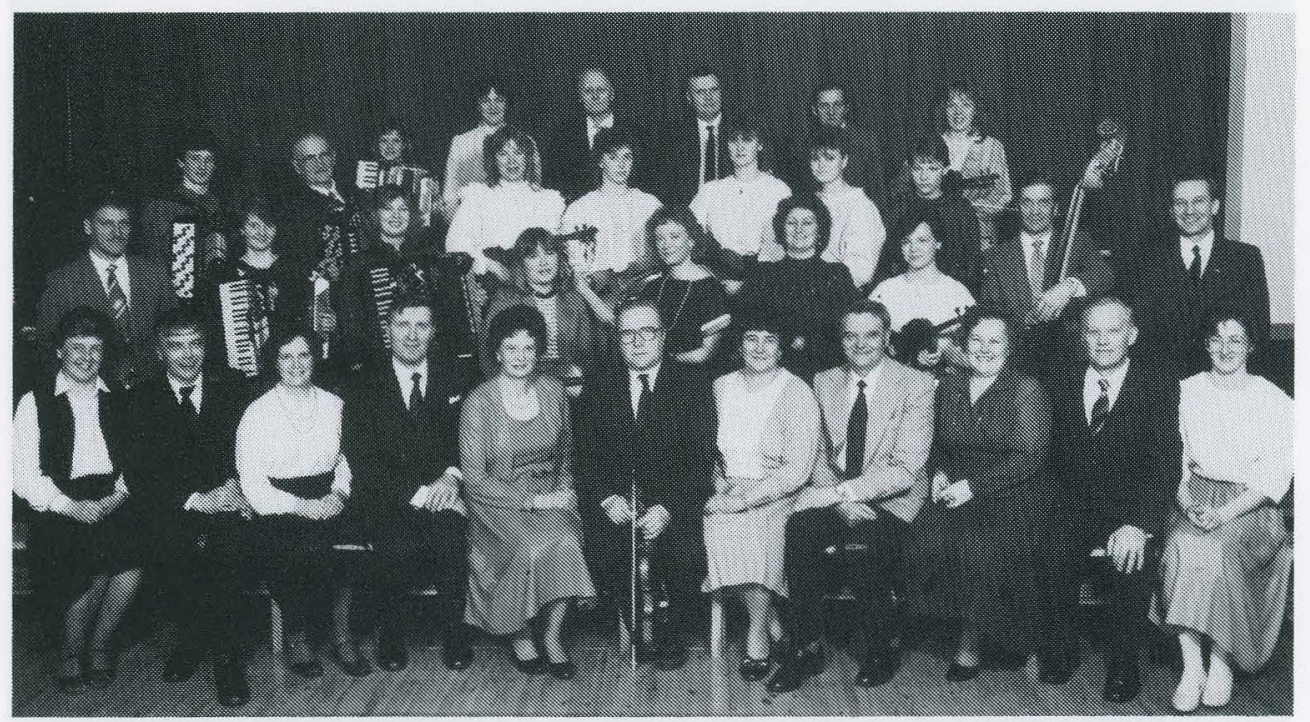

13:e april 1985 erhöll Jeppo bygdespelmän Europapriset $i$ folkkonst för sina insatser inom folkmusiken. Bilden är tagen från folkmusikparaden $i$ Vasa stadshus där spelmännen mottog priset. Spelledaren Elis Andersson framme i mitten.

(Finlands svenska folkmusikinstitut) 
I Nyland tröttnade man fortare än i Österbotten. Vid Brages tävling 1920 ställde inte längre de gamla vältränade spelmännen upp. Vasabladets signatur "Neger" gav tävlingen hård kritik. I synnerhet de ungas uppträdande fann han beklämmande. Om de yngre spelmännen säger han: "Som sprättar voro de ofta klädda och som 'musiksprättar' spelade de. Ett par av dem hade visserligen en aning om äldre melodier, men förvanskade dem helt och hållet genom sitt spel. Det var helt enkelt inga allmogespelmän mera, utan dåliga amatörer $i$ vanligt violinspel, som icke gjorde någon glad. --- om de ung a nyländska spelmännens uppvisning är ett verk av någon 'instruktör', då kan Nyland säga farväl åt sina allmogespelmän. För den instruktören bevare Gud svenska Österbotten! Det är de riktiga gamla spelmännen, som skola lära konsten åt de yngre, icke instruktörer från Helsingfors. "11

\section{"Slut er samman!"}

Efter denna spelmanstävling följde i södra Finland en tids avmattning. De flesta spelmän levde sitt stilla liv i hembygden som förut, uppträdde så smått vid bröllop och föreningsfester och lekte med fiolen hemma i sin stuga. På en del håll tillägnade sig de gamla gehörsspelmännen notkunskap och anslöt sig till bygdeorkestrar. Också inom Föreningen Brage i Helsingfors utgjorde bygdemusiken en del av stråkorkesterns repertoar.

Bara i Österbotten tävlade man som förut. Ännu på 1940- och 1950-talen var spelmanstävlingarna stora publiksuccéer. Spelmanstävlingar sändes också i radio på 1940-talet. Den 12 mars 1950 sändes en tävling från Kållby samlingshus i Pedersöre. Nytt var då, att spelmännen tävlade både enskilt och i tvåmannalag..$^{12} 1947$ uppträdde Vasa spelmansgille nio man starkt för första gången i radio. Gillets budskap till de österbottniska spelmännen var: Slut er samman i spelmansgillen!'³ Vid denna tid verkade spelmanslag redan bl.a. i Jeppo och i Lappfjärd.

Under 1950-talet ökade intresset för samspel. Finströms spelmanslag bildades 1952 och redan 1953 grundades Ålands spelmansgille, som från början var tänkt som ett samlande forum för de åländska spelmännen, men som fick karaktären av ett spelmanslag. Till de äldsta av våra nuverkande spelmanslag hör också Östra Nylands spelmansgille från 1956 och Tenala spelmanslag från 1958.

Redan på 1930-talet hade på olika håll röster höjts för en fastare organisation av spelmännen. 1934, då den XI Nordiska bygdeungdomsstämman hölls i Helsingfors, ville veteranspelmannen inom Finlands svenska folkdansring, Gunnar Granroth, samla alla de finlandssvenska spelmännen. Men intresset från spelmännens håll var obetydligt. Granroth lyckades endast få ihop ett tiotal spelmän, som i konservatoriets festsal framförde låtar i samlat lag. Initiativ till bildande av en riksorganisation för de finlandssvenska spelmännen togs på nytt på 1950-talet av folkdansringen. Ringens ordförande Sigurd Kjällman reste omkring i Åboland och i Nyland och samlade namn och adresser på ett hundratal spelmän. ${ }^{14}$ Hjälp i sitt arbete fick han av Klas Gustafsson i Borgå. En rundskrivelse sändes till spelmännen, men anslutningen var dålig. Klas Gustafsson gav inte tappt. Han sände ut skrivelser och cirkulär till spelmännen och till slut, 1967, lät han utlysa en finlandssvensk riksspelmansstämma i 15 dagstidningar. Inte en enda anmälan. ${ }^{15}$ Det skulle gå ända till 1969 innan ett tjugotal spelmän i Lappfjärd på Klas Gustafssons initiativ grundade Finlands svenska spelmansförbund. ${ }^{16}$ Sex år tidigare hade ett tiotal spelmän 


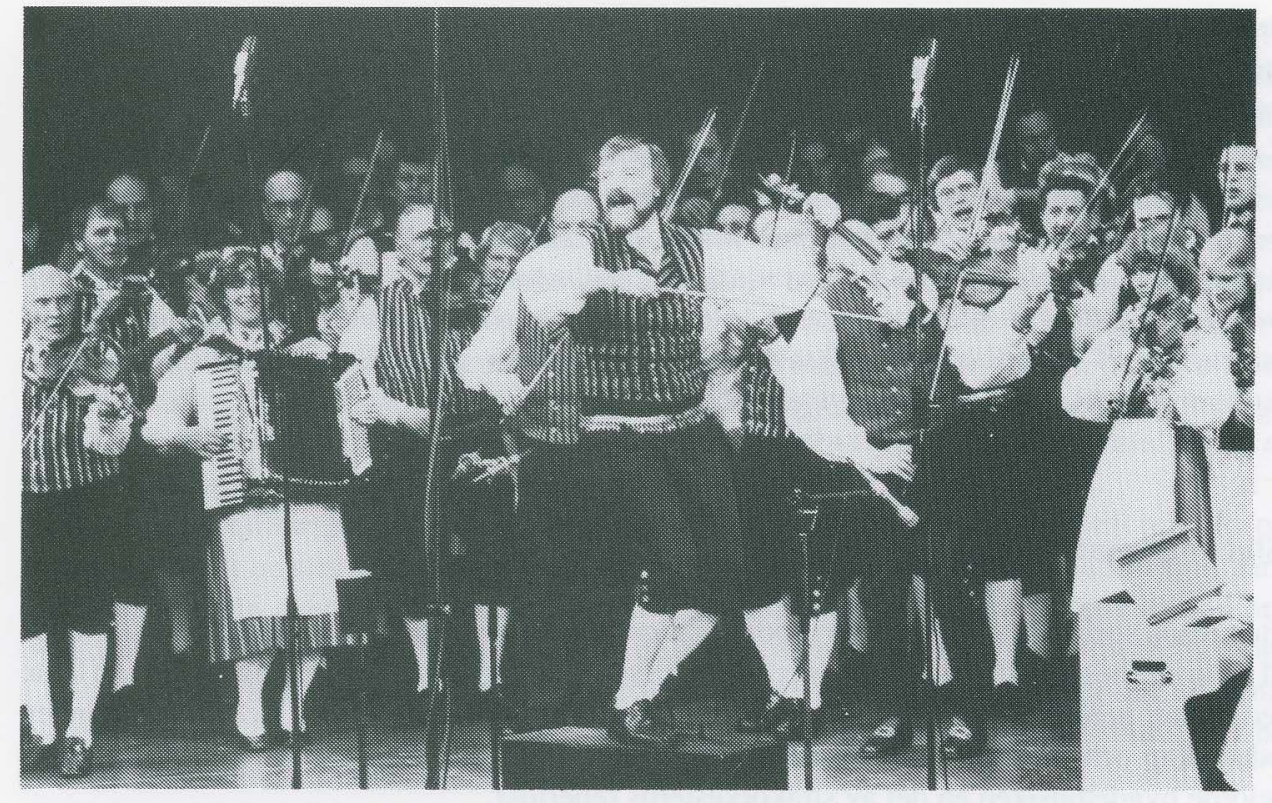

Spelmansmusik är fart och glädje, gemenskap och tradition. Jonas Borgmästars leder allspelet på Stadsteatern i Stockholm, april 1979.

Foto: Sverker Ström. (Finlands svenska folkmusikinstitut)

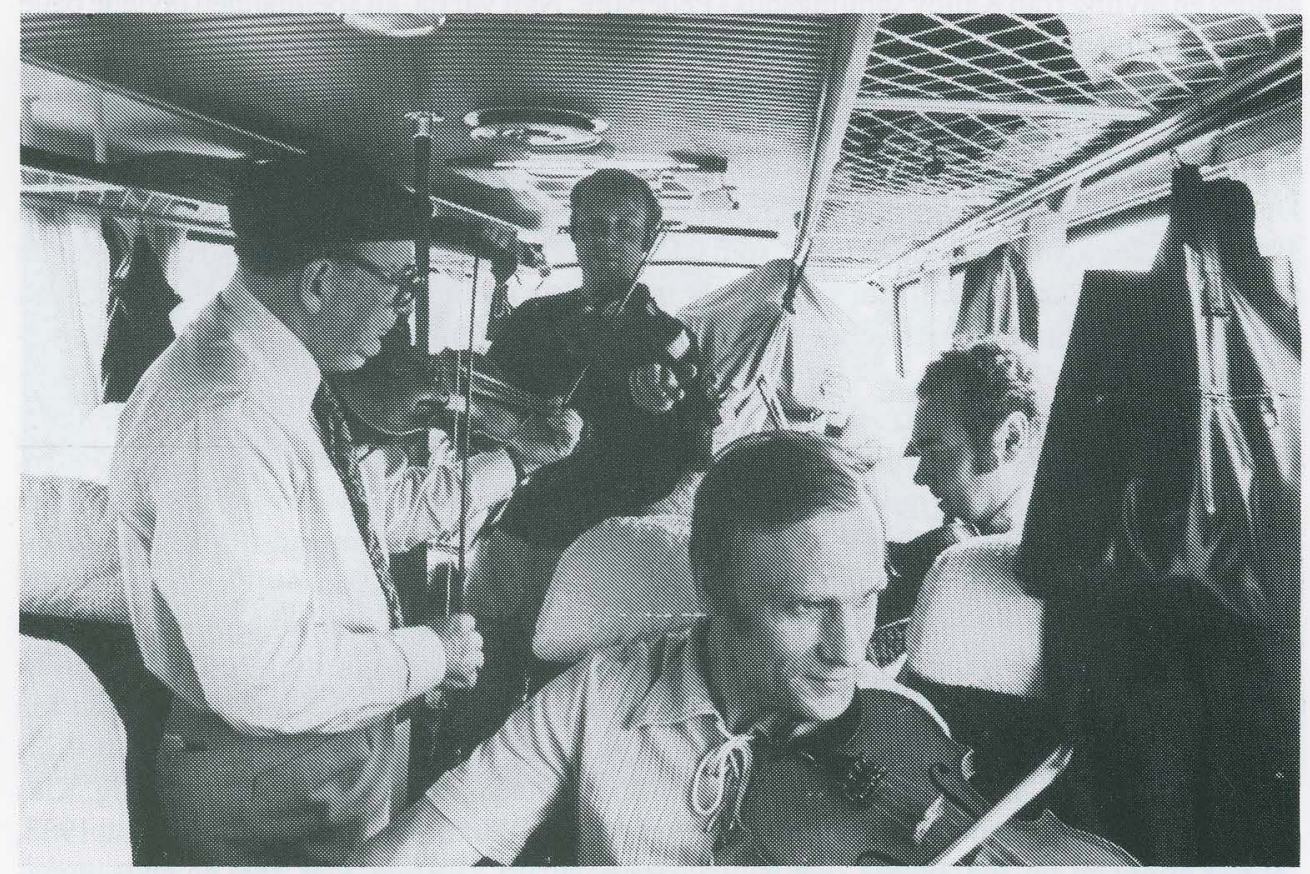

Buskspel i bussen. Nyländska spelmän på väg till spelmansstämman i Nykarleby 1977.

Foto: Reijo Turunen. (Finlands svenska folkmusikinstitut) 
i Vasa bildat Svenska Österbottens spelmansförbund, som verkade under lektor Arvid Nygårds ledning. Det österbottniska förbundet fick inte någon större livskraft, emedan största delen av de österbottniska spelmännen inte anslöt sig till förbundet.

\section{Folkmusiken - de stora festernas musik?}

Under slutet av 1960-talet och början av 1970-talet drog en folkmusikrenässans över hela världen. Nya organisatörer tog sig an detta slag av musik och folkmusiken började bjuda konstmusiken konkurrens i form av stora fester, som samlade ett stort antal musikanter att uppträda inför en stor lyssnande publik. I Finland kom detta till uttryck vid folkmusikfestivalerna i Kaustby; den första hölls 1968. Den musik, som haft sitt säte i de små miljöerna blev nu de stora sammankomsternas musik. Allmänhetens intresse växte, radio och tv började sända folkmusikprogram och olika skivbolag slogs om att få ge ut stora idolers och populära spelmansgruppers musik.

Verksamheten inom det nygrundade spelmansförbundet var de två första åren obetydlig. Endast Klas Gustafsson arbetade oförtrutet på, bl.a. utgav han åren 1970 och 1972 två nummer/ år av spelmansbladet "Fiolen min". Våren 1972 samlades ett hundratal spelmän till förbundsdag i Åbo och samma sommar anordnades den första finlandssvenska spelmansstämman i Tenala. Den var upptakten till en ny finlandssvensk spelmansrörelse. Också allmänheten blev nu medveten om att det fanns en finlandssvensk spelmanstradition, som var både rik och levande.

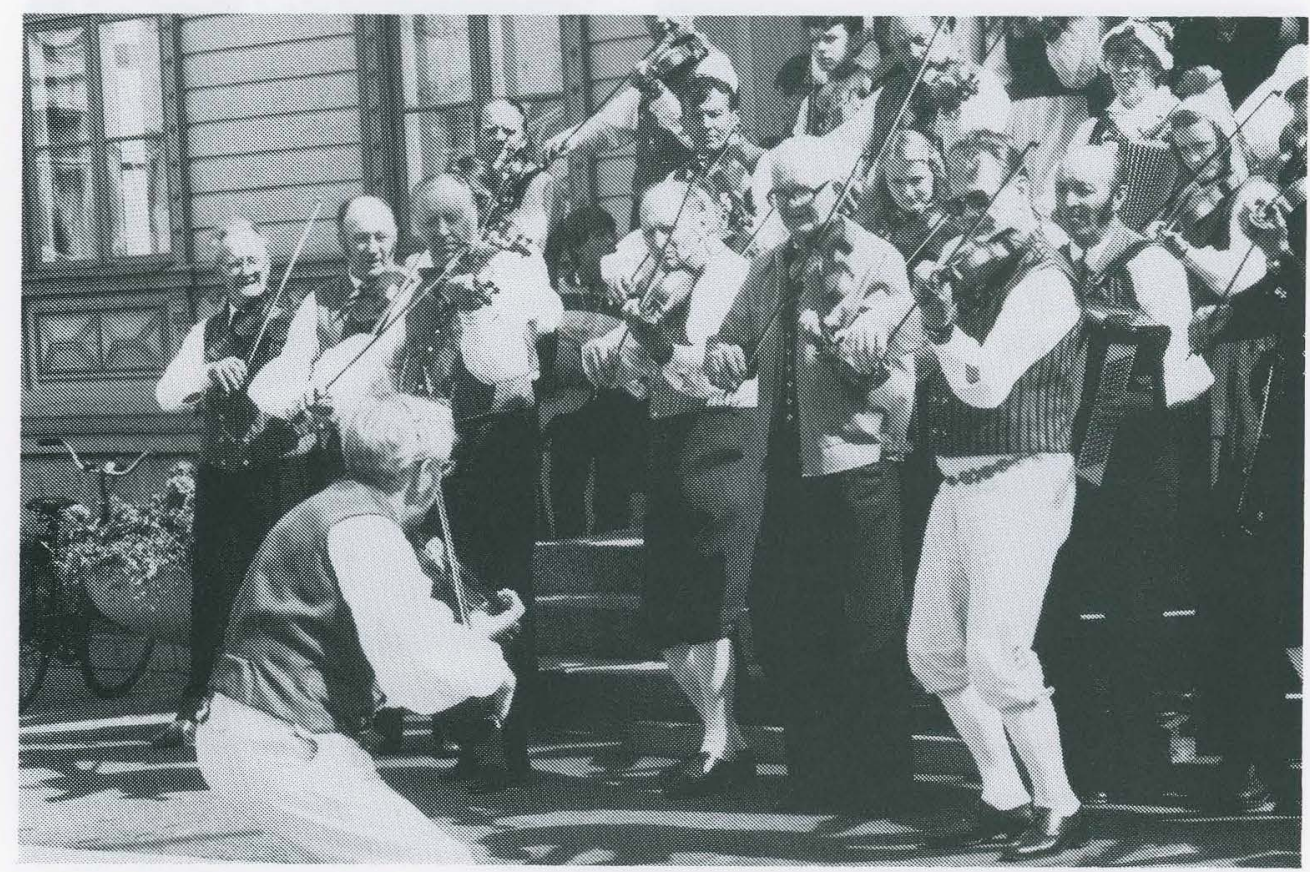

Spelmansstämman bjuder på en mångfald av aktiviteter under de drygt två dagar den pågår. Berg-Kalle alias Kalle Nyberg frän Tenala, leder spelet $i$ samband med spelmansstämman $i$ Kronoby 1979. Foto: Esko Salmela. (Finlands svenska folkmusikinstitut) 
Många av tidningarna var helt lyriska inför den ovanliga händelsen. Västra Nyland skrev bl.a.: "Säden stod guldgul och färdig till skörd. Solen lyste frän en molnfri himmel och sommaren stod i sin mognaste prakt. Hela naturen tycktes ha klätt sig i festskrud för att utgöra en värdig omramning till något man inte tror på är riktigt sant $i$ vår tid."

Redan vid denna första spelmansstämma utformades den stomme, som därefter skulle tillämpas vid alla spelmansstämmor: samling på fredagkväll, mindre konserter och dans på lördag, festtåg och festkonsert på söndag, stämmoavslutning med tacktal och gemensamt uppträdande av samtliga spelmän. Redan den andra spelmansstämman förde in spelmännen i kyrkan. Spelmansmusik i kyrkan var då någonting helt nytt och till en början kunde man förmärka en viss försiktighet från såväl församlingarnas som från spelmännens sida, vilket bl.a. tog sig uttryck i en osäkerhet i fråga om repertoarval. Musikandakterna har likväl givit spelmansmusiken en ny dimension och lett till ett flitigt nykomponerande av högtidliga låtar i traditionell stil.

Fram till 1974 leddes spelmansförbundet av Klas Gustafsson, då Ann-Mari Häggman övertog ordförandeskapet. Sedan 1979 har Kurt Sohlström verkat som ordförande i förbundet. Spelmännens antal har under förbundets historia mångdubblats; år 1972 räknade man med 200 aktiva spelmän i Finlands svenskbygder, nu räknar man med tusentalet. Spelmansförbundet har strävat till att stimulera intresset främst genom att anordna sammankomster, konserter och olika slag av kurser. Bland konsertframgångarna kan särskilt nämnas Storspelningen i Helsingfors år

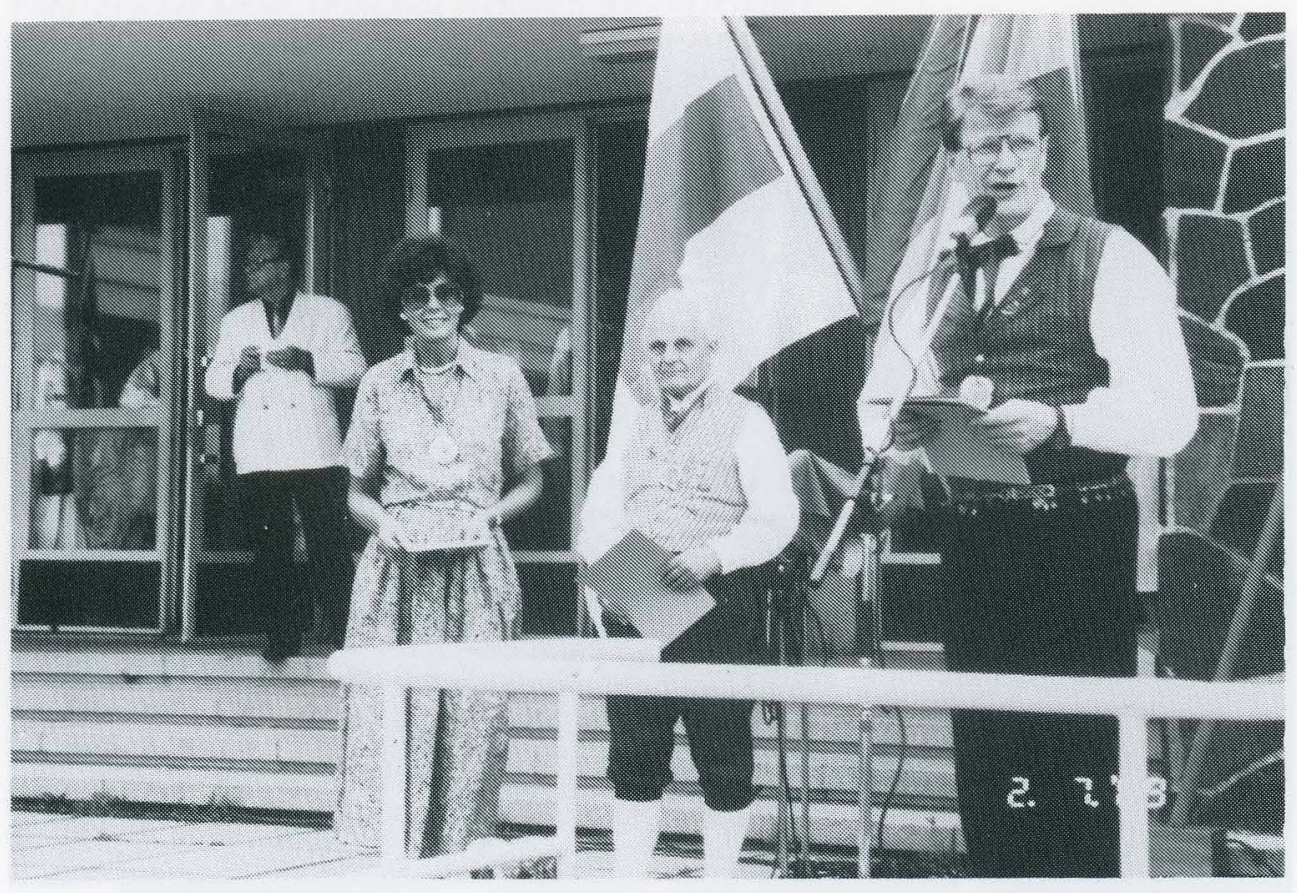

Tre ledargestalter på stämman i Borgå 1989; Ann-Mari Häggman, Klas Gustafsson och Kurt Sohlström. I bakgrunden riksdagsman och f.d. stadsdirektören i Borgå, P-H Nyman. (Finlands svenska folkmusikinstitut) 
1975, som fyllde hela Finlandiahuset med en entusiastisk publik och besöket på Stockholms stadsteater i april 1979, då spelmännen gav två konserter inför en fulltalig publik. Dessa evenemang uppmärksammades flitigt av massmedierna.

\section{Gruppspel och solospel}

Spelmanslagen har alltmer kommit att dominera den folkliga musikodlingen i bygderna. Lagen har vuxit fram som en direkt följd av de nya funktioner spelmansmusiken fått som estradmusik och som ackompanjemang till dans i stora paviljonger och föreningslokaler. Lagspelet är spelmännens sätt att hävda sig i dagens musikkonkurrens. Spelmanslaget blir förmodligen också det forum inom vilket de lokala traditionerna i framtiden kommer att vårdas och möta nya generationer.

Spelmanslagen är i dag spelmansförbundets ryggrad och verksamheten tar i stor utsträckning fasta på att stöda och uppmuntra lagen i deras verksamhet. Men koncentrationen kring spelmanslagen har också inneburit att den enskilda spelmannens insatser blivit mindre synliga. Gruppspelet döljer den individuella tolkningen och har en utjämnande inverkan på olika spelstilar. Spelmansförbundet har därför också strävat till att stöda det individuella spelet bl.a. genom att vid spelmansstämmorna uppmuntra sk buskspel dvs spontant improviserat musicerande. Stöd i sin strävan att uppmuntra de enskilda traditionsbärarna och det individuella spelet har spelmansförbundet fått av Finlands svenska folkmusikinstitut (gr. 1978). Folkmusikinstitutets uppgift är enligt stadgarna "att tillvarataga och stimulera intresset för folkmusik, både instrumental och vokal, samt att stöda, utforska och dokumentera den folkliga musikutövningen i Finlands svenskbygder". Sina syften förverkligar insitutet genom forskning och publicering av material om finlandssvensk folkmusik, genom att anordna seminarier och folkmusiktillställningar och genom att betjäna i ärenden som rör folkmusik. Folkmusikinstitutet har sedan 1980 regelbundet anordnat sk traditionshörnor vid spelmansstämmorna. I traditionshörnan skall enskilda spelmän och sångare beredas plats att uppträda under mer inofficiella former. Med anledning av att traditionshörnan introducerades vid spelmansstämman i Närpes 1980 skrev Lars Huldén en dagboksvers, som träffande och humoristiskt återgav situationen:

När sexhundra man drar till med en schottis är man väl en pottis ochleller bigottis om inte man av den musiken behagas. Det dundrar och dånar och vriner och vringstar som en gång i tiden Pappenheims hingstar när Stålhandskes finnar med storm skulle tagas. En byspelmans ton är så tunn som en myggas, men viktigt är att dess hörbarhet tryggas.

Det liknar musik när i hörnan den lagas. 17 


\section{Spelmansmusiken - närsamhällets musik}

Våra folkmusikaliska traditionsbärare intar en särställning inom den stora skaran av musikutövare i det svenska Finland. Spelmannens starka lokala anknytning och musikens fasta förankring i närsamhällets historia och traditioner skiljer honom från andra musiker. Anmärkningsvärt är att den finlandssvenska spelmansmusiken fortfarande saknar professionella utövare. Denna rika och brokiga musiksektor uppbäres helt av människor, som får sin utkomst genom ett annat yrke. Deras begåvning och intresse får dem att ägna folkmusiken sin fritid.

Den finlandssvenska spelmansmusiken har i dag ett gott stöd av en riksorganisation. Spelmansstämmorna har blivit folkmusikens stora pr-tillfällen, som ger publicitet, pengar och status. Men det är inte de stora festerna som gör spelmansmusiken. Det är den verksamhet, som året om sker ute i bygderna. Det är de lokala spelmännens låtar och variationerna i tolkningen av musiken, som ger spelmansmusiken dess egenart. Mer än någon annan musikform är spelmansmusiken därför närmiljöns musik. Så länge musiken har en stark ställning i sin hemmiljö har den också de bästa förutsättningarna att utvecklas och leva vidare.

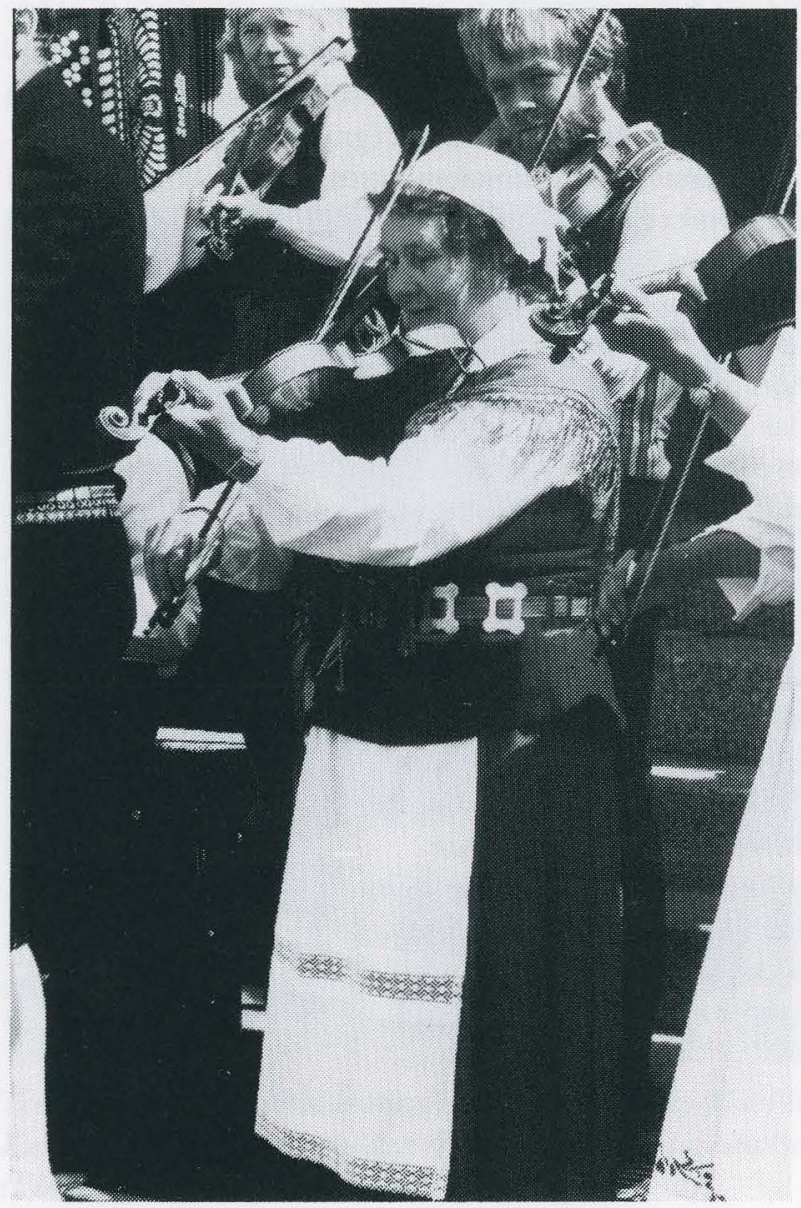

Två spelmansprofiler från Åbolands skärgård; t.v. Vera Holmström frän Houtskär, Mossala och t.h. Aspö-Erik, alias Erik Jansson frain Korpo. Foto: Esko Salmela. (Finlands svenska folkmusikinstitut) 


\section{Källor:}

1. Tidningsurklipp i Finlands svenska folkmusikinstitut, FMI 1,p: Vbl 13.4 1985, Hbl 13.4 1985, Pohjalainen 13.4 1985, JT 13.4 1985, Öb 13.4 1985, Pohjalainen 15.41985 etc.

2. Folkkultursarkivets samling SLS 83, s. 6 .

3. Otto Andersson, Om den österbottniska folkdansen. SFV Kal. 1903, s. 141.

4. Spelmansrörelsens första tider i Sverige beskrivs ingående av Otto Andersson i "Spel opp I spelemänner", Stockholm 1958.

5. Brages Årsskrift 1906, s. 6.

6. Hufvudstadsbladet 8.61907 .

7. Nya Pressen 8.61907.

8. Hufvudstadsbladet 21.71911.

9. Vasabladet 26.61921.

10. Folkkultursarkivets band 1977:47.

11. Vasabladet 1.71920.

12. Ivar Lunabba: Spelmansmusiken i Pedersörebygden. Pedersörebygdens sång och musikförbund 1923-1973. Festskrift red. Ole Nordström. Jakobstad 1973, s. 113.

13. Vasabladet 13.51947.

14. "Ringen" vill samla ihop spelmännen. Hufvudstadsbladet 30.10 1954; Samling av bygdespelmän. Folkdansaren, mars 1955.

15. Klas Gustafsson, Till allmogespelmän i Finlands svenskbygder. Fiolen min 1/1970, s. 3-11.

16. Finlands svenska spelmansförbunds protokoll 25.11969.

17. Hufvudstadsbladet 1.71980.

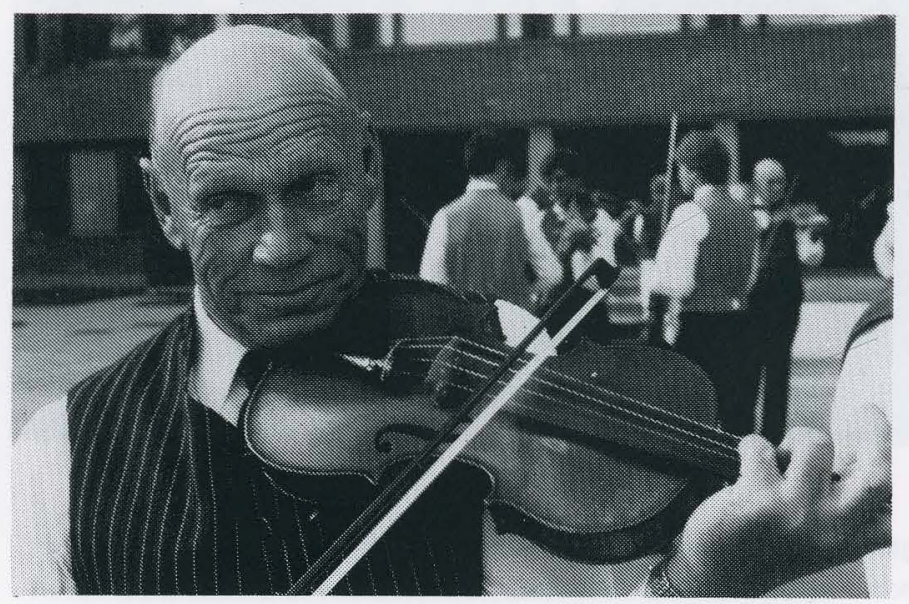




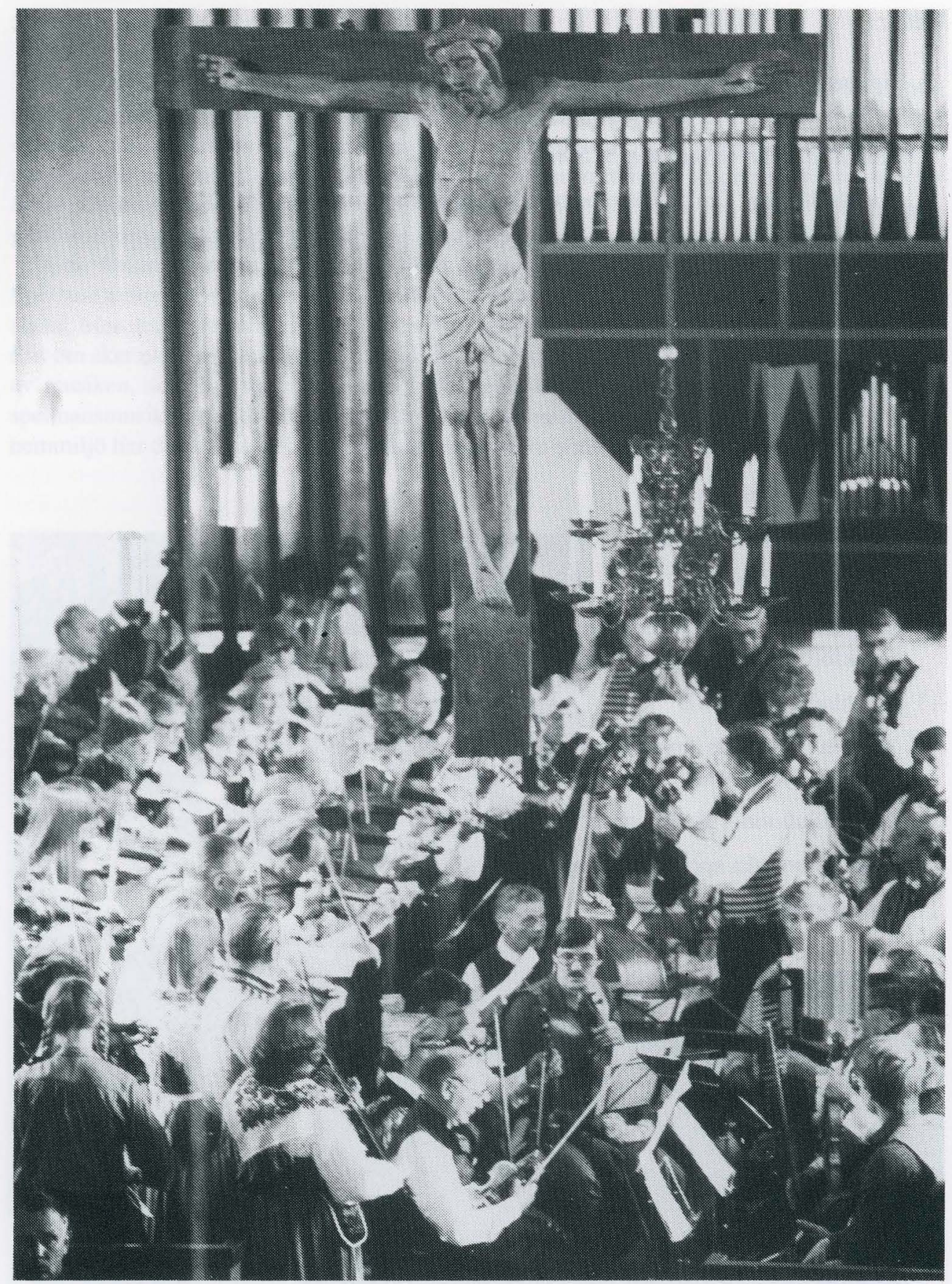

En viktig ingrediens på en spelmansstämma är kyrkspelet. Bilden är från Närpes 1980.

Foto: Esko Salmela. (Finlands svenska folkmusikinstitut) 


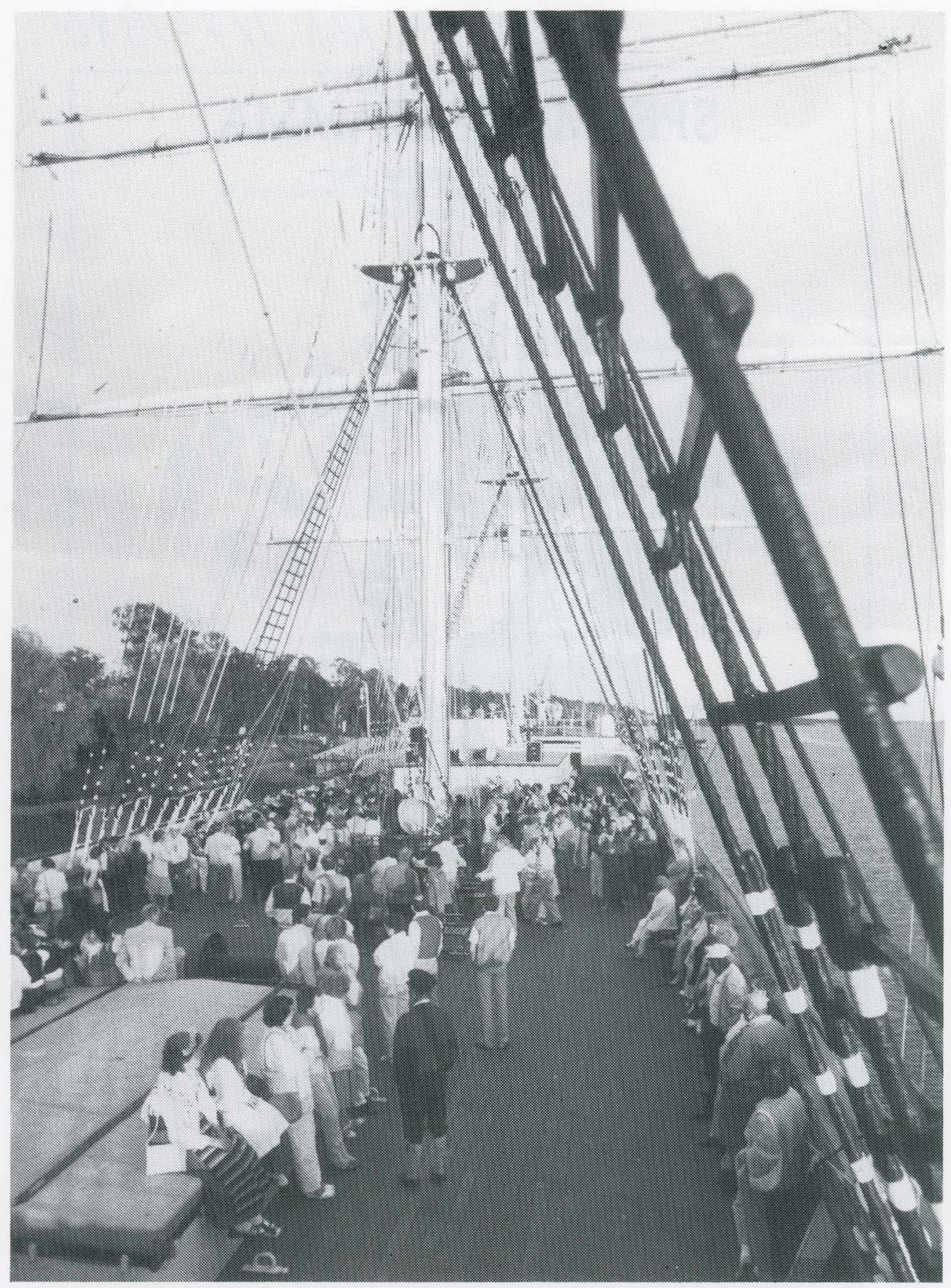

Dans på Pommerns däck - spelmansstäman i Mariehamn 1986.

Foto: Esko Salmela. (Finlands svenska folkmusikinstitut) 


\section{SPELMANSSTÄMMA}

På spelmansstämman i Närpes

hade inrättats en särskild traditionshörna för enskilda framträdanden.

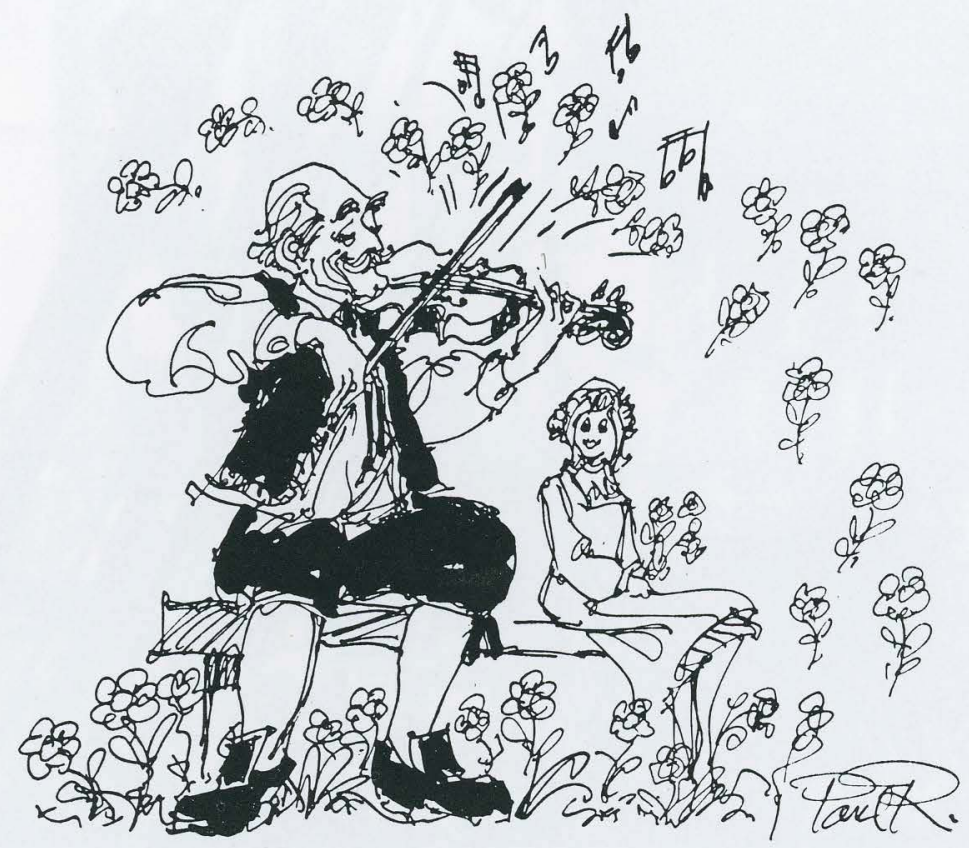

När sexhundra man drar till med en schottis är man väl en pottis och'eller bigottis om inte man av den musiken behagas.

Det dundrar och dånar och vriner och vringstar som en gång $i$ tiden Pappenheims hingstar när Stålhandskes finnar med storm skulle tagas. En byspelmans ton är så tunn som cn myggas, men viktigt är att dess hörbarhet tryggas. Det liknar musik när $i$ hörnan den lagas.

Wang $H u$

Hufvudstadsbladets dagbokssida uppmärksammade folkmusikinstitutets första traditionshörna med en vers av signaturen Wang Hu, alias Lars Huidén. 

ISBN 952-9669-00-3 